\section{Biological Properties of Experimental Methacrylate-Based Sealers Containing Calcium Phosphates}

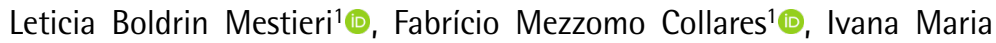
Zaccara ${ }^{1}$, Maria Stella Nunes Araujo Moreira ${ }^{2}$, Patrícia Maria Polli Kopper $^{1} \mathbb{D}$, Vicente Castello Branco Leitune ${ }^{1} \mathbb{D}$, Fabiana Soares Grecca ${ }^{1}$ (D)

This study aimed to evaluate, in vitro and in vivo, the biocompatibility of experimenta methacrylate-based endodontic sealers containing $\alpha$-tricalcium phosphate $(\alpha-T C P)$ or nanostructured hydroxyapatite (HAp). Experimental methacrylate-based dual-cure sealers with the addition of $\alpha$-TCP or HAp, at 10\%wt were formulated and compared to AH Plus (AHP). Cell viability was assessed by 3-(4,5-dimethyl-thiazoyl)-2,5-diphenyl-tetrazolium bromide (MTT), and sulforhodamine B (SRB). Sealers were implanted in rats' subcutaneous tissue and histologically evaluated. Bioactivity was assessed by alkaline phosphatase enzyme activity (ALP) and Alizarin Red (AR), using apical papillary cells (SCAPs), and by the bone deposition measured in surgical cavities on rats' femur filled with AH Plus or $\alpha-$ TCP. In both viability assays, HAp and AHP sealers were similar, and $\alpha-$ TCP presented lower viability compared to the others at MTT assay $(p<0.05)$. A gradual decrease of the inflammatory response according to the periods was observed and AHP was the only that presented giant cells (7-day period). Collagen fibers condensation increased according to the periods, with no differences among sealers. There was an increase at ALP activity and mineralized nodules deposition according to periods. HAp and $\alpha$-TCP presented higher values for ALP activity at 5 days and at 5,10 , and 15 days for AR and were different from AHP $(p<0.05)$. $\alpha$-TCP presented superior values at 10 and 15 days compared to HAp and AHP for AR $(p<0.05)$. At 90 days, $\alpha$-TCP and control (empty cavity) showed high bone deposition compared to AHP ( $p<0.05)$. $\alpha$-TCP and HAp, in a methacrylate-based sealer, presented biocompatibility and bioactivity, with the potential to be used as endodontic sealers in clinical practice. Further investigations are required to gain information on the physicochemical properties of these sealers formulation before its clinical implementation.
'Department of Conservative Dentistry, School of Dentistry, UFRGS - Universidade Federal do Rio Grande do Sul, Porto Alegre, RS, Brazil

${ }^{2}$ Post-Graduate Program, School of Dentistry, UNIB Universidade lbirapuera São Paulo, SP, Brazil

Correspondence: Fabiana Soares Grecca. Av. Ramiro Barcelos, 2492, 90035-003 Porto Alegre, RS, Brasil. Tel: + 55-51-3308-5197. e-mail: fabiana.grecca@ufrgs.br

Key Words: $\alpha$-tricalcium phosphate, biocompatibility, cytotoxicity, hydroxyapatite, root canal sealer.

\section{Introduction}

Endodontic sealers present contact with the periapical tissue when the canals are sealed, or even, may be unintentionally extruded beyond the apical foramen. The contact of the sealers with the periradicular tissues elicits effects on bone metabolism and regeneration, making sealers evaluation by biological assays such as cell viability, histocompatibility, and bioactivity essential.

Calcium phosphate is a biomaterial widely used in the biomedical area due to its biocompatibility and osteoconduction/osteoinduction potential (1). Experimental sealers containing variations of this compound in a polymer base have been studied in vitro, showing moderate cytotoxicity in human gingival fibroblasts and in one mouse fibroblast cell line (2), reducing endodontic biofilm and maintaining the push-out bond strength $(2,3)$.

Hydroxyapatite (HAp) is a more stable calcium phosphate with low solubility, being used as filler for composite resins, adhesive systems, and root canal sealers $(4,5,6)$. Studies evaluating experimental endodontic sealers with HAp demonstrated biocompatibility in the animal model (7), presented bioactivity in vitro $(8,9,10,11)$, and showed appropriate physicochemical properties as setting time, flow, solubility, microhardness, and bond strength $(8,9,10,11)$. In addition, $\alpha$-tricalcium phosphate $(\alpha-$ TCP) is a reactive compound that presents high biodegradation rate and progressive dissolution with formation of calcium apatite (12). These calcium phosphates could interact with surrounding tissues, increasing the mineral deposition and biological response.

Collares et al. added nanostructured HAp to methacrylate-based sealer (4), different radiopacification agents (13) or $\alpha$-TCP and chlorhexidine (14). The authors observed satisfactory radiopacity and film thickness without, however, influencing other properties $(4,13)$, and provided antibacterial property and potential to improve periapical healing (14). Moreover, the association of $\alpha$-TCP or nanostructured HAp to the methacrylate base experimental sealer showed bond strength, degree of conversion, and film thickness similar to AH Plus, and displayed higher amounts of calcium ions release (10). 
The use of the same resin matrix used for restorative materials (i.e. adhesive system, composite resin) allows the production of a dual cured sealer, with reliable properties. Although, only few methacrylate-based sealers were available, methacrylate-based restorative materials associated with adhesive dentistry have been used since the 1960s, with great success.

The combination of the physicochemical effect of this methacrylate-based sealer with potential biocompatibility properties of calcium phosphates may lead to the development of an improved root canal sealer, compared to commercially available sealers. Commercially available resin-based endodontic sealers are usually chemically cured, and probably present no bioactivity properties because they do not contain calcium silicate based components. The presence of calcium phosphate associated with methacrylate sealer could promote mineral deposition and consequently a biological sealing of root apex.

Thus, the aim of this study was to evaluate, in vitro and in vivo, the cell viability, the reaction of rats' subcutaneous connective tissue and the bioactivity of experimental methacrylate-based endodontic sealers containing $\alpha$-tricalcium phosphate ( $\alpha$-TCP) or nanostructured hydroxyapatite (HAp).

\section{Material and Methods}

\section{Ethical Considerations}

This study was structured in accordance with the principles of the National Council for the Control of Animal Experimentation (CONCEA, Brazil), and approved by the Institutional Review Board (protocol number 38542614.6.0000.5347) and the Institutional Review Board on Animal Studies (protocol number 30466).

\section{Formulation of Experimental Sealers}

The experimental methacrylate-based dual-cure root canal sealers were prepared according to a previous study (11). The base resin was formulated by mixing $70 \mathrm{wt} \%$ of urethane dimethacrylate (UDMA), $15 \mathrm{wt} \%$ of glycerol1,3-dimethacrylate (GDMA), 15 wt $\%$ of ethoxylated bisphenol A glycol dimethacrylate (BISEMA), 1 mol\% of camphorquinone (CO), $1 \mathrm{~mol} \%$ of $\mathrm{N}, \mathrm{N}$-dihydroxyethylpara-toluidine (DHEPT), and $1 \mathrm{~mol} \%$ of benzoyl-peroxide (BP) (Esstech Inc., Essington, PA, USA). 10 wt $\%$ of each hydroxyapatite (HAp) or $\alpha$-tricalcium phosphate ( $\alpha$-TCP) were used with a mean particle size of $26.7 \mathrm{~nm}$ and 6.03 $\mu \mathrm{m}$, respectively. Ytterbium Fluoride (YbF3) was used as radiopacifier (40wt\%).

\section{Isolation and Culture of Scaps}

Stem cells from apical papilla (SCAPs) were collected from third molars at the stage of incomplete root formation via apical opening and stored in a culture dish $(35 \times 10 \mathrm{~mm}$; TPP - Techno Plastic Products, Zollstrasse, Trasadingen, Swiss) containing Minimum Essential Medium Eagle - Alpha Modification ( $\alpha-M E M$, Sigma-Aldrich, St. Louis, MO, USA) supplemented with 10\% fetal bovine serum (FBS, Gibco, Grand Island, NY, USA) and 1\% penicillin and streptomycin $(\mathrm{P} / \mathrm{S}$, Gibco). The tissues were sectioned into fragments of approximately $1 \mathrm{~mm}^{3}$ and kept in an incubator at $37^{\circ} \mathrm{C}$, $100 \%$ humidity and $5 \% \mathrm{CO}_{2}$. The culture medium was changed $24 \mathrm{~h}$ after tissue collection and at every $48 \mathrm{~h}$ to obtain explants of SCAPs. After 80\% confluency, cells were washed with PBS 1X (Sigma-Aldrich), separated with Trypsin-EDTA 0.25\% solution (Sigma-Aldrich), re-suspended in culture medium and transferred to a Falcon tube (TPP), thus forming a cell suspension that was transferred to cell culture bottles (TPP) that were kept in an incubator at $37^{\circ} \mathrm{C}, 100 \%$ humidity and $5 \% \mathrm{CO}_{2}$ until reaching $80 \%$ of confluence. Successive passages were prepared for cellular expansion, and the experiments were performed at the fourth cell passage.

\section{Characterization of Scaps}

To show mesenchymal cells potential, SCAPs were submitted to a flow cytometer analysis using specific molecular markers of mesenchymal cells. For this, the cells were incubated with fluorescein isothiocyanate (FITC)coupled anti-human monoclonal antibodies against the antibodies CD105, CD146, CD45 and CD14 (Santa Cruz Biotechnology Inc, Santa Cruz, CA, USA) at 1:100 dilution for $30 \mathrm{~min}$ at $4{ }^{\circ} \mathrm{C}$. Cell suspensions were washed twice with PBS and resuspended in $1 \mathrm{~mL}$ of PBS containing $0.1 \%$ FBS for analysis on a flow cytometer (FACS Calibur; BD Biosciences) using the CellQuest PROTM software (BD Biosciences).

\section{Elutes Confection}

For the achievement of elutes, the experimental sealers (paste/paste) and AH Plus (Dentsply, York, PA, USA) were manipulated, placed in a 12-well plate (TPP) $(n=4)$ and filled with $\alpha$-MEM supplemented with 10\% FBS and 1\% $\mathrm{P} / \mathrm{S}$ (314.0 $\mathrm{mm}^{2}$ area and $3.0 \mathrm{~mm}$ height). After hand-mixed, the experimental sealers were photo-activated with a 1200

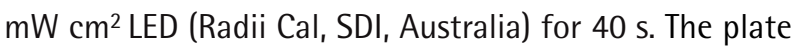
was incubated at $37^{\circ} \mathrm{C}, 100 \%$ humidity and $5 \% \mathrm{CO}_{2}$ for $24 \mathrm{~h}$ and the elutes were collected in sterile Falcon tubes (100\% concentration). A concentration of $10 \%$ of the elutes, diluted in culture medium, was used for viability assays.

SCAPs ( $1 \times 10^{4}$ cells per well) were seeded on two 96well plates (TPP) using $\alpha$-MEM supplemented with 10\% $\mathrm{FBS}$ and $1 \% \mathrm{P} / \mathrm{S}$. One day after plating, cells were exposed to the sealers elutes (100 $\mu \mathrm{L}$ per well). The experiments were performed in triplicate and repeated at three 
independent times.

\section{Viability Assays}

Cell viability was assessed by 3-(4,5-dimethyl-thiazoyl)2,5-diphenyl-tetrazolium bromide (MT, Sigma-Aldrich), which evaluates the cell's mitochondrial respiration by quantification of the enzyme mitochondrial succinate dehydrogenase, and sulphorhodamine B (SRB, SigmaAldrich), which evaluated the cell's protein content. The assays were performed $24 \mathrm{~h}$ after cell exposure.

For MT evaluation, $10 \mu \mathrm{L}$ of a $5 \mathrm{mg} / \mathrm{mL}$ MTT solution were added in each well, followed by incubation for $3 \mathrm{~h}$ at $37^{\circ} \mathrm{C}, 100 \%$ humidity and $5 \% \mathrm{CO}_{2}$. After this period, the wells' contents were removed, and the colorimetric product solubilized in $100 \mu \mathrm{L}$ of acidified isopropanol $(\mathrm{HCl} 0.4 \mathrm{~N}$, Sigma-Aldrich). The optical densities of the solutions were measured in a spectrophotometer at $570 \mathrm{~nm}$ wavelengths.

For SRB evaluation, $25 \mu \mathrm{L}$ of a $50 \%$ trichloroacetic acid solution (Sigma-Aldrich) was added in each well, followed by incubation for $1 \mathrm{~h}$ at $4^{\circ} \mathrm{C}$. After this period, the wells' contents were removed and $100 \mu \mathrm{L}$ of SRB dye $(0.4 \%)$ was added in each well for $30 \mathrm{~min}$. The plate was washed with 1\% acetic acid solution (Sigma-Aldrich) and $100 \mu \mathrm{L}$ of Trizma Base (10mM) (Sigma-Aldrich) was added to solubilize the colorimetric product. The optical densities of the solutions were measured in a spectrophotometer at $560 \mathrm{~nm}$ wavelengths.

For both experiments, $\alpha$-MEM was used as a negative control. Cell viability was expressed as a percentage of the mean of negative control, which was considered to represent $100 \%$.

\section{Biocompatibility Assay}

Eighteen male Wistar rats (Rattus norvegicus) aged 18 weeks were used for the experiments and divided in three groups, according to the experimental periods: 7, 30 and 90 days ( $n=6 /$ group). The animals were anesthetized with $0.008 \mathrm{~mL} / 100 \mathrm{~g}$ ketamine and $0.004 \mathrm{~mL} / 100 \mathrm{~g} 2 \%$ xylazine hydrochloride (Virbac do Brasil Indústria e Comércio Ltda., São Paulo, SP, Brazil). An area with approximately $10 \mathrm{~cm} 2$ was disinfected with alcohol-iodine solution after the dorsal skin was shaved. Four $0.5 \mathrm{~cm}$-long incisions were made on the animals' backs, $2 \mathrm{~cm}$ from the spine and at least 2 $\mathrm{cm}$ apart from one another, and 4 surgical cavities were made using blunt-tipped scissors. Three sterile polyethylene tubes $(10 \mathrm{~mm} \times 1 \mathrm{~mm})$ containing the evaluated materials and one empty tube (control group - CT) were placed into the surgical cavities parallel to the incision; the position in which each tube was implanted was randomized. The incisions were closed using 3-0 silk suture (Johnson \& Johnson Produtos Profissionais Ltda., São José dos Campos, SP, Brazil).
At the end of each experimental period, the animals were euthanized by anesthetic overdose with $120 \mathrm{~mL} / \mathrm{kg}$ pentobarbital (Syntec do Brasil Ltda., Cotia, SP, Brazil). Biopsy of the implant area was immediately carried out with a 1-cm safety margin and fixed in 10\% formalin solution for $24 \mathrm{~h}$. Specimens were embedded in paraffin, and 3-umthick sections were obtained and stained with hematoxylin and eosin. Two blinded and calibrated examiners $(\kappa=0.77)$ analyzed the sections by light microscopy (Olympus BX41Olympus America Inc., Melville, NY, USA), at 40, 100, 400, and $1000 \times$ magnification.

The inflammatory content was determined by the presence of neutrophils, eosinophils, giant cells, macrophages and lymphoplasmacytic cells. The events were classified according to the following scores (15): 0) Absent: inflammation was either absent or within blood vessels; 1) Mild: cells were present although sparse or in reduced clusters; 2 ) Moderate: cells were present but did not dominate the microscopic field; 3 ) Intense: cells were present in the form of an infiltrate close to the material used. Fiber condensation was classified according to the following scale: 0) Absence of collagen fibers; 1) Presence of a thin layer of collagen fibers; 2) Presence of a thick layer of collagen fibers. Abscess formation was classified as follows: 0) No abscess; 1) Presence of abscess in contact with the surgical cavity in which the material had been inserted; 2) Presence of abscess areas far from the surgical cavity in which the material had been inserted.

\section{Bioactivity Assays}

Bioactivity was assessed by alkaline phosphatase enzyme activity (ALP), considered a marker of osteoblastic and odontoblastic activity and Alizarin Red staining (AR), which identifies calcium and phosphate deposits in cell culture, both at the periods of 1, 5, 10 and 15 days, and by bone deposition measured in surgical cavities on rats' femur filled only with the AH Plus and $\alpha$-TCP.

For ALP evaluation, a commercial kit (Fosfatase Alcalina, Labtest Diagnóstica, Lagoa Santa, MG, Brazil) was used. Cells were lysed with $0.1 \%$ sodium docecyl sulfate solution (SDS, Sigma-Aldrich) for $30 \mathrm{~min}$ and the experiment were performed according to the protocol described in the kit. Optical density was measured in a 96-well plate at 590 $\mathrm{nm}$ wavelength in a spectrophotometer (Thermo Fischer Scientific Inc., Waltham, MA, USA), and the absorbance readouts were normalized by the number of viable cells at the respective culture period.

For AR evaluation, cells were fixed with 10\% paraformaldehyde solution (Sigma-Aldrich), washed with distilled water and stained with AR 2\% - pH 4.2 (SigmaAldrich). The wells were photographed (Canon EOS-1D; Canon Inc, Tokyo, Japan) for qualitative analysis of 
mineralized nodules formation. For quantitative analysis by absorbance evaluation, the nodules were solubilized with 10\% cetylpyridinium chloride (Sigma-Aldrich) for $15 \mathrm{~min}$, and the optical density was measured in a 96-well plate at $562 \mathrm{~nm}$ wavelengths in a spectrophotometer (Thermo Fischer Scientific Inc.).

Moreover, the experimental sealer $\alpha$-TCP was compared to AHP in the bone deposition measured in filled surgical cavities on rats' femur. Twelve male Wistar rats (Rattus norvegicus) aged 18 weeks were used for the experiments, that were divided into two groups, according to the experimental periods: 30 and 90 days ( $n=6 /$ group).

The animals were anesthetized with $0.008 \mathrm{~mL} / 100 \mathrm{~g}$ ketamine and $0.004 \mathrm{~mL} / 100 \mathrm{~g} \mathrm{2 \%}$ xylazine hydrochloride (Virbac do Brasil Indústria e Comércio Ltda, São Paulo, SP, Brazil).

Trichotomy of the right leg was made, followed by disinfection with an alcohol-iodine solution. Linear cutaneous and muscular incisions were performed with a 15-knife scalpel blade, tissues were separated by layers and the periosteum was incised with a scalpel. Three $6-\mathrm{mm}-$ diameter cavities were prepared on the cortical surface of the femur, $5 \mathrm{~mm}$ apart from each other, with a slow-rotation Surgical cavities were randomly divided according to the groups: AH Plus, $\alpha$-TCP and control (empty cavity - CT). The incisions were closed in layers (Vicryl Ethicon, Johnson \&

$\mathrm{SP}$, Brazil) and $50 \mathrm{mg} / \mathrm{kg}$ of an opioid analgesic (Tramal, Pfizer Indústria Farmacêutica, Guarulhos, SP, Brazil) was injected intramuscularly.

At the end of each experimental period, the animals were euthanized by anesthetic overdose with $120 \mathrm{~mL} /$ $\mathrm{kg}$ pentobarbital (Syntec do Brasil Ltda, Cotia, SP, Brazil). The operated leg was disarticulated and dissected to isolate the femur, and with a slow-rotation diamond disc the bone was transversally sectioned to separate the surgical cavities Tissue specimens were fixed in $10 \%$ formalin solution for $24 \mathrm{~h}$, decalcified using Anna Morse solution (20\% sodium citrate $+50 \%$ formic acid), embedded in paraffin and 3-mm-thick sections were obtained and stained with hematoxylin and eosin. Three blinded and

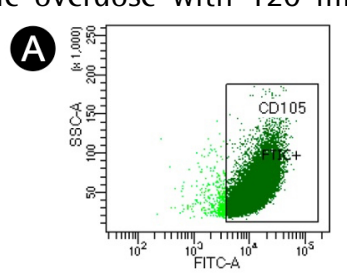

calibrated examiners $(\alpha=0.79)$ analyzed the slices under a light microscope (Olympus BX41- Olympus America Inc., Melville, NY, EUA), using 40 and 100x magnification. The samples were photographed (Canon EOS-1D; Canon Inc, Tokyo, Japan), and hard tissue deposition was analyzed by the software ImageJ. The area of the wound (100\%) and the new formatted bone were measured and calculated to obtain the percentage of bone deposition according to periods.

\section{Statistical Analysis}

Data were analyzed regarding normality (Shapiro-Wilk), and statistical analyses were performed using Kruskal-Wallis test and Dunn's post hoc (in vivo assay) and ANOVA and Tukey's post hoc (in vitro assays), at a significance level of 5\% (GraphPadPrism 7 Software).

\section{Results}

\section{Characterization Assay}

SCAPs expressed typical levels of mesenchymal stem cell surface markers (Fig. 1). The cultures expressed positivity for mesenchymal stem cell markers (CD105, 90\%, and CD146, 86.6\%), whereas the hematopoietic cell markers (CD45, 0.6\%, and CD14, 0.1\%) were absent or minimally expressed (Fig. 1, A).

\section{Viability Assays}

For MT assay, HAp and AHP did not presented statistical differences from each other ( $p>0.05)$, and $\alpha$-TCP presented a lower viability result, being statistically different from the other sealers and the control (CT) $(p<0.05)$ (Fig. 1, B). For $\mathrm{SRB}$ assay, all evaluated sealers presented lower viability
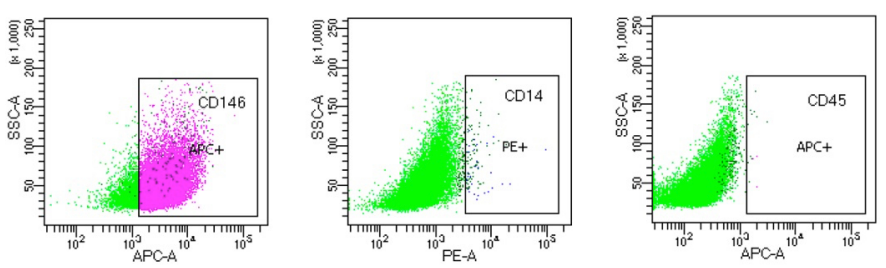

B

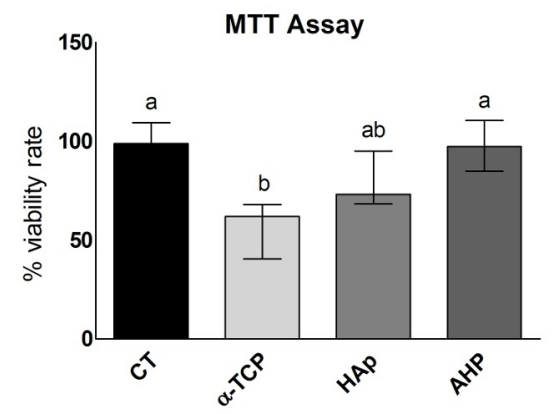

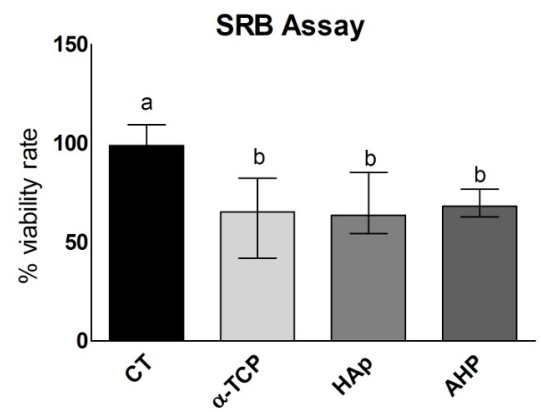

Figure 1. In vitro assays. a) Immunophenotyping of stem cells from apical papilla (SCAPs) by flow cytometry after four passages. Expression of the STR01, CD146, CD105, CD45 and CD14 markers. b) Results of viability assays of the sealers and control in human dental papilla stem cells (SCAPs). Different lowercase letters represent statistical difference between groups. 
than the control $(p<0.05)$, and no statistical differences from each other ( $p>0.05)$.

\section{Biocompatibility Assay}

The results are summarized in Figure 2. There were no abscesses and eosinophils reported. Compared to the control, no material showed a significant difference in the lymphoplasmacytic cells, macrophages, and neutrophils at all study periods ( $p>0.05$ ). Regarding the inflammatory content at 7 days, $\alpha$-TCP and HAp showed no differences to the control (CT) ( $p>0.05)$ and AHP showed statistical differences to the control $(p<0.05)$, presenting the highest scores. Furthermore, the AHP was the only presenting giant cells, at the 7-day period (Fig. 2B).

Inflammatory content and macrophages scores were higher at the 7-day period, decreasing at 30 and 90 days, with no statistical differences ( $p>0.05)$. HAp presented statistical differences for lymphoplasmacytic cells at 7 days compared to 30 days, with a decrease in the score $(p<0.05)$.

Formation and condensation of new collagen fibers occurred from the first (7 days) until the last evaluated period (90 days), with no differences among sealers and control $(p>0.05)$.

\section{Bioactivity Assays}

The results are summarized in Figure $3(A, B$ and $C)$ and Figure 4 ( $A$ and $B)$.

HAp, $\alpha-T C P$, and control presented higher values for ALP activity at 5 days and were different from AHP $(p<0.05)$. At 10 days, $\alpha$-TCP presented the higher enzyme activity outcomes, differing from the other sealers and control $(p<0.05)$, that were similar to each other $(p>0.05)$. At 15 days, $\alpha$-TCP presented higher values when compared to AHP $(p<0.05)$, but no statistical differences were found among these sealers and the groups HAp and control (p>0.05). (Fig. 3A)

At 1 day, no statistical differences were found among sealers and control ( $p>0.05)$. AHP presented the lowest values for AR when compared with HAp, $\alpha-\mathrm{TCP}$, and control at 5,10 , and 15 days $(p<0.05)$. At 10 and 15 days, $\alpha-$ TCP presented the highest values, being similar to control $(p>0.05)$ and different from the other sealers $(p<0.05)$. (Fig. $3 \mathrm{~B}$ and C)

At in vivo bioactivity assay, none of the sealers and control presented closing total of bone cavities at 90 days period. The percentage of bone deposition increased from 30 days to 90 days period for $\alpha$-TCP and control $(p<0.05)$. The highest percentage of bone deposition levels at the 30 days was observed at control $(p<0.05)$, while $\alpha$-TCP and AHP presented not statistically different results ( $p>0.05) . \alpha-$ TCP and control showed similar results at 90 days ( $p>0.05$ ), differing from AHP $(p<0.05)$.

\section{Discussion}

The addition of calcium phosphate to endodontic sealers aims to develop a bioactive material to improve the complete regeneration of the damaged apical periodontal attachment and surrounding bone (16).

Although a commercially available methacrylate-based sealer presents no satisfactory clinical results, methacrylatebased sealers were developed and studied over the past years, presenting reliable physicochemical properties and the possibility of a dual cured system. HAp and $\alpha$-TCP were used to produce experimental methacrylatebased sealers with promising physicochemical results $(4,10,13,14)$. However, biological studies are necessary to understand the possibilities of these sealers.

An experimental sealer composed of calcium phosphate in a methacrylate base presented acceptable results of the cell viability in primary human gingival fibroblasts and in
Figure 2. In vivo assays. a) Results of biocompatibility assays of the sealers and control in the subcutaneous tissue of rats. Statistical differences between groups at the same period were demonstrated with an asterisk $(*)$ on the graph. Statistical difference between periods at the same group was demonstrated with a delta symbol ( $\delta$ ) on the graph. b) Illustrative images of histological findings. A) Giant cells (arrows) at AHP (7 days, 40X); B) Neutrophil (arrow) and vessels at $\alpha$-TCP (7 days, 100X); C) Macrophages (arrows) at HAp (7 days, 100X); thick layer of collagen fiber at $\alpha$-TCP (D) and HAp (E) (90 days, 20X); F) Normal tissue aspect at control (CT) (90 days, 10X). 
A

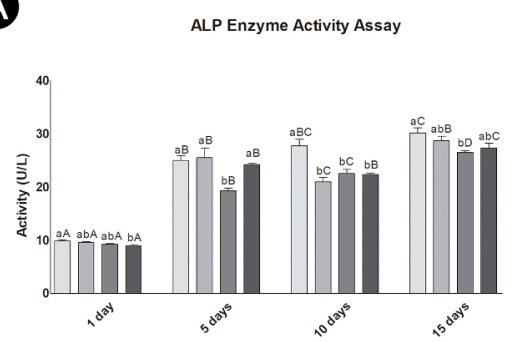

C

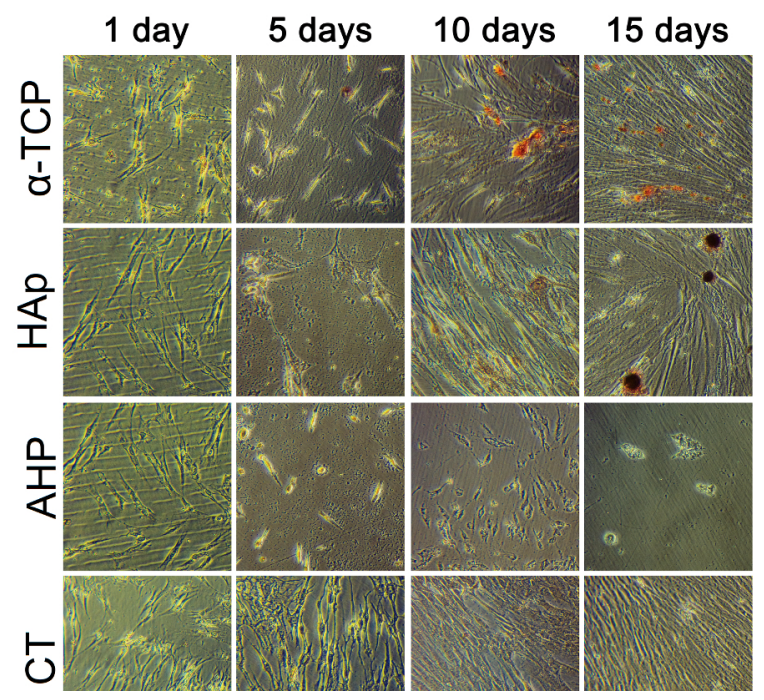

Figure 3. (A) Alkaline phosphatase enzyme activity; (B) mineralized nodule formation quantification by Alizarin Red dye and, (C) illustrative images of mineralized nodule formation by Alizarin Red dye in stem cells from apical papilla (SCAPs) after treatment with sealers and control (CT) at different periods. Different
lowercase letters represent statistical differences among the sealers in the same period. Different capital letters represent statistical differences among the periods at the same sealer.

mouse fibroblasts (L929) (2), corroborating with the present findings, which demonstrated that, even when associated with a methacrylate base, the sealers presented slight cytotoxicity when evaluated by MTT and SRB, minimizing the adverse effects of this resin on the biological response $(17,18,19)$. According to ISO 10993-5 (20), a material exhibits slight cytotoxicity above $60 \%$ cell viability and is considered non-cytotoxic above $90 \%$.

Biocompatibility assay aimed to simulate the direct contact of endodontic sealers to the periapical region, getting in contact with the connective tissue from this area. The inflammatory content and collagen fibers condensation are substantially associated with the healing process.

The outcomes of this study showed a higher amount of inflammatory cells at the first period (7 days), with higher scores to AHP when compared with the control, and a gradual decrease of those cells across the periods, associated with an increase in collagen fibers condensation for all evaluated sealers. In addition, AHP was the only group that presented giant cells at the 7-day period, corroborating previous studies (21). The experimental sealers with calcium phosphate addition used in this study showed good biocompatibility, with similar results to the control. To the best of our knowledge, methacrylate-based sealers without calcium phosphate addition present intense inflammation levels $(22,23)$.

The high degree of conversion presented in the experimental methacrylatebased sealers might be related with the interesting results (14), differing from the conventional methacrylate sealers that, due to the high amounts of monomers that could leach from the bulk of polymer and diffuse to the tissue, demonstrated toxicity (24) It might be assumed that the decrease in leachability could jeopardize the calcium phosphate elution, thus decreasing the remineralization property.

All sealers showed ALP activity, increasing over the evaluation periods. The AR assay showed an increase in the deposition of mineralized nodules during the evaluation periods, with the exception of AHP, demonstrating that the experimental sealers containing calcium phosphates present bioactivity. This result can be associated with the liberation of calcium and phosphate ions from the experimental sealers, since they can act on cellular metabolism, stimulating proliferation, differentiation, and inducing mineralization in vitro $(1,3,8,9,11,12,25,26,27,28)$.

HAp presents lower solubility than $\alpha$-TCP (16) corroborating to the results of this compound in the AR assay. $\alpha$-TCP is designed to be degraded and substituted by bone, justifying its high hydrolysis $(12,29)$. Due to the favorable outcomes of $\alpha$-TCP at the in vitro bioactivity assays, this sealer was chosen to perform the bioactivity in vivo methodology.

The results demonstrated the highest percentage of bone deposition at 90 days period for $\alpha$-TCP and control, and lowest percentage to AHP, proving that the association of this compound was not modified by the presence of methacrylate resin in the experimental sealer. The high osteoconductivity, which is indicated by the increase in ALP 
A

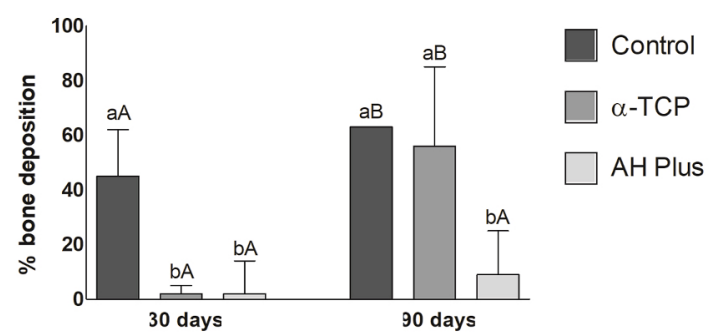

B

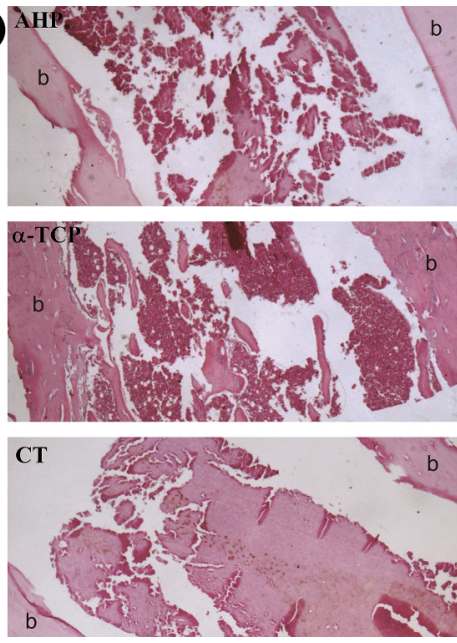

Figure 4. A) Bone deposition (\%) in rats' femur after treatment with AH Plus and experimental sealer ( $\alpha$-TCP) at 30 and 90 days. Different lowercase letters represent statistical difference between the groups at the same period. Different capital letters represent statistical difference between the periods at the same group. B) Illustrative images of bone deposition for AH Plus (AHP), $\alpha$-TCP and control (CT) after 30 days, the cortical bone of the sample is represented with a letter $b$.

enzyme activity, enhance of osteoblasts' activity, deposition of mineralized tissue and accelerated bone formation (27), explaining the results.

In vitro methodologies presented are commonly used to assess the viability of dental materials in different cell lines $(1,2,17,18,25,16,30,31,32)$. Stem cells from apical papilla (SCAPS) are mesenchymal stem cell and the apical papilla is responsible for root development. SCAPs have demonstrated higher proliferation and differentiation potential than dental pulp stem cells (DPSCs) (33) and can differentiate into odontoblast-like cells forming dentin when implanted into the subcutaneous space of immunocompromised mice using hydroxyapatite/tricalcium phosphate (HAp/TCP) as a carrier vehicle (31).

In conclusion, the calcium phosphate compounds evaluated in this study, $\alpha$-TCP and HAp, in a methacrylatebased sealer, presented biocompatibility and potential to be used as endodontic sealers in clinical practice. Further investigations are required to gain information on the physical, chemical, of this sealer formulation before its clinical implementation.

\section{Resumo}

0 objetivo deste estudo foi avaliar a biocompatibilidade de cimentos endodônticos experimentais à base de metacrilato contendo fosfato $\alpha$-tricálcico ou hidroxiapatita nanoestruturada in vitro e in vivo. Cimentos experimentais de cura dual à base de metacrilato com a adição de fosfato de $\alpha$-tricálcico ( $\alpha$-TCP) ou hidroxiapatita (HAp), a 10\% em peso, foram formulados e comparados com AH Plus (AHP). Viabilidade celular foi avaliada por brometo de 3- (4,5-dimetil-tiazoil) -2,5-difenil-tetrazólio (MTT) e sulforodamina B (SRB). Cimentos foram implantados no tecido subcutâneo dos ratos e avaliados histologicamente. Bioatividade foi avaliada pela atividade da enzima fosfatase alcalina (ALP) e Alizarin Red (AR) utilizando células da papila apical (SCAPs) e pela deposição óssea, medida em cavidades cirúrgicas no fêmur de ratos preenchidos com AH Plus e $\alpha$-TCP. Nos dois ensaios de viabilidade, HAp e AHP
AR $(p<0,05)$. Aos 90 dias, $\alpha$-TCP (cavidade vazia) apresentaram maior deposição de tecido ósseo quando comparado ao AHP $(p<0,05)$. $\alpha$-TCP e HAp, presentes nos cimentos à base de metacrilato, apresentaram biocompatibilidade $\mathrm{e}$ potencial para serem utilizados como seladores endodônticos na prática clínica. Investigações adicionais são necessárias para obter informações sobre as propriedades físico-quimicas dessas formulações de cimentos antes de sua implementação clínica.

\section{Acknowledgments}

The authors would like to thank Coordination of Higher Level Personnel Improvement (CAPES) for the financial support; Nucleus of Dental Basic Research (UFRGS) and Institute of Basic Sciences in Health (UFRGS) for the support for the experiments.

\section{References}

1. Yang $H-L$, Sun $H$. Calcium phosphate scaffolds combined with bone morphogenetic proteins or mesenchymal stem cells in bone tissue engineering. Chin Med J. 2015;128:1121-1127.

2. Khashaba RM, Chutkan NB, Borke JL. Comparative study of biocompatibility of newly developed calcium phosphate-based root canal sealers on fibroblasts derived from primary human gingiva and a mouse 1929 cell line. Int Endod J 2009;42:711-718.

3. Wang $L$, Xie $X$, Li C, Liu $H$, Zhang $K$, Zhou $Y$ et al. Novel bioactive root canal sealer to inhibit endodontic multispecies biofilms with remineralizing calcium phosphate ions. J Dent 2017;60:25-35.

4. Collares FM, Leitune VCB, Rostirolla FV, Trommer RM, Bergmann cp, samuel smw. nanostructured hydroxyapatite as filler for methacrylatebased root canal sealers: hanano in root canal sealers. Int Endod J 2012;45:63-67.

5. Raghavendra SS, Jadhav GR, Gathani KM, Kotadia P. Bioceramics in Endodontics - a Review. J Istanb Univ Fac Dent 2017;51:S128-S137.

6. Washio A, Morotomi T, Yoshii S, Kitamura C. Bioactive glass-based endodontic sealer as a promising root canal filling material without semisolid core materials. Materials (Basel) 2019;12:3967.

7. Jacob G, Kumar A, Varughese J, Varghese N, Harikrishna Varma P et al. Periapical tissue reaction to calcium phosphate root canal sealer in porcine model. Indian J Dent Res 2014;25:22-27.

8. Portella FF, Collares FM, dos Santos LA, dos Santos BP, Camassola M, Leitune VCB et al. Glycerol salicylate-based containing $\alpha$-tricalcium phosphate as a bioactive root canal sealer: $\alpha \mathrm{TCP}$ bioactive root canal sealer. J Biomed Mater Res B Appl Biomater 2015;103:1663-1669. 
9. Jerri Al-Bakhsh BA, Shafiei $F$, Hashemian A, Shekofteh $K$, Bolhari $B$, Behroozibakhsh M. In-vitro bioactivity evaluation and physical properties of an epoxy-based dental sealer reinforced with synthesized fluorine-substituted hydroxyapatite, hydroxyapatite and bioactive glass nanofillers. Bioact Mater 2019; 28:322-333.

10. Rostirolla F, Leitune VCB, Bohns FR, Portella FF, Samuel SMW, Collares FM. Calcium Phosphates as Fillers for Methacrylate-Based Sealer. Clin Oral Investig. 2019;23:4417-4423.

11. Toledano $M$, Muñoz-Soto $E$, Aguilera FS, Osorio $E$, Pérez-Álvarez MC, Garcia- Menocal JA, et al. R. The mineralizing effect of zinc oxidemodified hydroxyapatite-based sealer on radicular dentin. Clin Oral Investig 2020;24:285-299.

12. Padilla S, Roman J, Sanchezsalcedo S, Valletregi M. Hydroxyapatite/ sio2-cao-p2o5 glass materials: in vitro bioactivity and biocompatibility. Acta Biomater 2006;2:331-342.

13. Collares FM, Ogliari FA, Lima GS, Fontanella VRC, Piva E, Samuel SMW. Ytterbium trifluoride as a radiopaque agent for dental cements: ytterbium trifluoride for dental cements. Int Endod J 2010;43:792-797.

14. Collares FM, Leitune VCB, Portella FF, Santos PD, Balbinot GS, dos Santos LA et al. Methacrylate-based root canal sealer containing chlorexidine and $\alpha$-tricalcium phosphate. J Biomed Mater Res B Appl Biomater 2018;106:1439-1443.

15. Figueiredo JA, Pesce HF, Gioso MA, Figueiredo MA. The histological effects of four endodontic sealers implanted in the oral mucosa: submucous injection versus implant in polyethylene tubes. Int Endod J 2001;34:377-385.

16. Ling LE, Feng L, Liu H-C, Wang D-S, Shi Z-P, Wang J-C et al. The effect of calcium phosphate composite scaffolds on the osteogenic differentiation of rabbit dental pulp stem cells: calcium phosphate composite scaffolds and osteogenic differentiation of RDPSCS. J Biomed Mater Res A 2015;103:1732-1745.

¿ 17. Pinna L, Brackett MG, Lockwood PE, Huffman BP, Mai S, Cotti E et al. In Vitro cytotoxicity evaluation of a self-adhesive, methacrylate resin-based root canal sealer. J Endod 2008;34:1085-1088.

18. Al-Hiyasat AS, Tayyar M, Darmani H. Cytotoxicity evaluation of various resin based root canal sealers. Int Endod J 2010;43:148-153.

19. Rossato TCA, Gallas JA, da Rosa WLO, da Silva AF, Piva E, Peralta SL, et al. Experimental sealers containing metal methacrylates: physical and biological properties. J Endod 2017;43:1725-1729.

20. ISO standards 10993-5. Biological evaluation of medical devices. Tests for cytotoxicity: in vitro methods. International Organization for Standardization, Geneva, Switzerland. 2009.

21. Baldasso FER, Kopper PMP, Morgental RD, Steier L, de Figueiredo JAP,
Scarparo RK. Biological tissue response to a new formulation of a silicone based endodontic sealer. Braz Dent J 2016;27:657-663.

22. Scarparo RK, Grecca FS, Fachin EVF. Analysis of tissue reactions to methacrylate resin-based, epoxy resin-based, and zinc oxide-eugenol endodontic Sealers. J Endod 2009;35:229-232.

23. Silva LAB, Azevedo LU, Consolaro A, Barnett F, Xu Y, Battaglino RA, et al. Novel endodontic sealers induce cell cytotoxicity and apoptosis in a dose-dependent behavior and favorable response in mice subcutaneous tissue. Clin Oral Investig 2017;21:2851-2861.

24. White $S$, Wong J, Caputo A, Li P. Microleakage of adhesive resinous materials in root canals. J Conserv Dent 2013;16:213-218.

25. Zordan-Bronzel CL, Tanomaru-Filho M, Rodrigues EM, Chavez-Andrade GM, Faria G, Guerreiro-Tanomaru JM. Cytocompatibility, bioactive potential and antimicrobial activity of an experimental calcium silicate-based endodontic sealer. Int Endod J 2019;52:979-986.

26. Giacomino CM, Wealleans JA, Kuhn N, Diogenes A. Comparative biocompatibility and osteogenic potential of two bioceramic sealers. J Endod 2019;45:51-56.

27. Barrère $F$, van der Valk $C M$, Dalmeijer RAJ, Meijer $G$, van Blitterswijk CA, de Groot K et al. Osteogenecity of octacalcium phosphate coatings applied on porous metal implants: osteogenecity of ocp coatings. J Biomed Mater Res A 2003;66:779-788.

28. Weir MD, Ruan J, Zhang N, Chow LC, Zhang K, Chang X et al. Effect of calcium phosphate nanocomposite on in vitro remineralization of human dentin lesions. Dent Mater 2017;33:1033-1044.

29. Ferracane JL. Hygroscopic and hydrolytic effects in dental polymer networks. Dent Mater 2006;22:211-222.

30. Silva EJ, Rosa TP, Herrera DR. Evaluation of cytotoxicity and physicochemical properties of calcium silicate-based endodontic Sealer MTA Fillapex. J Endod 2013;39:274-277.

31. Sonoyama $W$, Liu $Y$, Fang D, Yamaza $T$, Seo BM, Zhang $C$ et al. Mesenchymal stem cell-mediated functional tooth regeneration in swine. PLoS ONE 2006;1:e79.

32. Saberi EA, Karkehabadi $H$, Mollashahi NF. Cytotoxicity of various endodontic materials on stem cells of human apical papilla. Iran Endod J 2016 11:17-22.

33. Huang GTJ, Sonoyama W, Liu Y, Liu H, Wang S, Shi S. The hidden treasure in apical papilla: the potential role in pulp/dentin regeneration and BioRoot Engineering. J Endod 2008;34:645-651.

Received August 10, 2020 Accepted October 10, 2020 